\title{
Economic aspects of media globalization
}

\author{
Zeljko Rutovic \\ Ministry of Culture \\ Montenegro \\ zeljko.rutovic@mku.gov.me
}

\begin{abstract}
This paper descriptively analyzes only one important segment of the globalization process, which concerns interdependent relationship between the economy and the media. It critically and selectively illuminate the economic effects of media globalization through the prism of consequent negative externalities of five types of dual relations: global and local, supranational and national, public and private, real and virtual, media and meta-media. It starts from two hypotheses: 1) that the polarity of those relations is caused through and by the influence of concentration of the corporate media, or convergent interests of the media, politics and business; and 2), that there is a priority of economic impulses and motives of a big capital in relation to the conglomerate of all other interests - political, social, cultural, media and others. In conclusion, it ascertains the verification of these hypotheses.
\end{abstract} $8330.2016 / 9-2 / 18$

Keywords: media, globalisation, economic interests, media concetration

JEL Classification: F02; L82

\section{INTRODUCTION}

In addition to the important political role, media in contemporary society have a remarkable and growing economic influence. The political role of media, among other things, consists of interpreting the political and economic relations; communicational linking of social subsystems of authorities, politicians and citizens; representing interests and statuses of social groups; initiating and conducting the public hearings; influencing the public opinion, and so on. The economic role of media is reflected in its dominant orientation to the profit. Today, media is one of the largest industries in the world. The aforesaid raises questions about their proper role in public life, or demystification of the media role and importance for the society. Civil society has a lot of institutions that are independent of the state and authority, through which citizens express their interests. Hence, the civil nature of media is indisputable. By definition, it stems from the complete, accurate and timely informing of all citizens about the major events and processes in society and its environment. Therefore, media must be equally accessible to all entities, witnessing all social events. But, in reality, it is not everything as it has been written in the various documents and literature. Why is it so?

The modern "civilizational package" of media, in accordance with the dominant interests and position of some narrow social groups and nomenclature authority, relatively successfully transforms the famous 
scheme the master-and-servant into the story about the global division on the super-developed riches (ie. the leaders), and the super-underdeveloped poor (which can conditionally be reffered to as the periphery). Thanks to the institutional, technological, political, economic and other influences, there is a real possibility (risk), with a great and apparently uncritical help (the power) of the media, that there are pushed social pathology, quasi-value, sensationalism, consumerism are so on. There is also a possibility that the media are programmed to transfer our present and our future from the zone of uncertainty and ambiguity into the dangerous zone of predictability and predestination. This is done in various ways, inter alia, by selecting and inserting information, through manipulation, global propaganda, and thematic television. In this sense, daily could be seen, heard and read in the mass media that a new global "order" in many places and territories brings disorder, dictatorship, authoritarianism, totalitarianism, neo-fascism, dictation, wars, riots, protests, mass migration, etc...

Media reports can have a significant impact on public opinion in both global and local relations. In addition, media are not even a little bit immune to various types of assistance to the strongest, in the sense that their power is transformed from the protective function, via spheres of influence, to the dominance, super-power, and omnipotence. Because, the media's "fourth power" is often closely intertwined with political power. It is enormously dependent on the private interests of owners and controllers of media. Therefore, the media have paradoxically and substantially lost control and critical function. Many authors call those phenomena: the media imperialism. Thus, for example. O. Boyd-Barret (1977, p. 117 writes: "the process whereby the ownership, structure, distribution of content of the media in any one country are single or together subject to substantial external pressures from the media interests of any other country or countries without proportionate reciprocation of influence by the country are affected."

\section{THE CONTRASTS OF GLOBALIZATION AS A CONTRADICTORY CONTEXT}

Last three decades represent a period of new historical development. It is often identified with globalization (Draskovic and Jovovic, 2006; Bandin, 2009; Draskovic, 2010a; Ćábelková et al., 2015), and characterized by paradigmatic changes that occur extremely unevenly across hybrid and heterogeneous processes of universalization of economic, technological, media, institutional, cultural and other flows. These processes and flows are opposed, controversial and contradictory. They virtually include all aspects of life and society. The alleged universalization, homogenization, and unification of the world for some important (often imposed) principles, guidelines, and standards of behavior poses a serious challenge for all nation states, economies, and politics in terms of their sovereignty, cultural and national identity. Therefore, an opened question remains regarding possibile preservation of their identity and specificity, the method and level of their integration into the global trends, development opportunities, and finding the best forms of strategic adjustment (Bandin, 2009).

Positive and negative results of globalization have the opposite context. They represents a big challenge of time and space of the contemporary civilization. Many outcomes of global changes (e.g. geopolitical and environmental) are uncertain and dangerous for mankind. Practice has shown that the institutions of civil society as regulatory instruments of protecting people against the authorities, do not act universally and globally. They are denied by a variety of national, corporate, alternative, and informal group structure. Those are various organizational forms of "elite" (Draskovic, 2010a; Draskovic and Delibasic, 2014), which are superior in welth, power and/or technological development. Those put economic motives to the forefront of globalization, combined with political, media and other instruments of implementation. These economic motives impose a number of restrictions for individuals, nations, and even individual states. The manifesta- 
tion of their actions is implemented at local and global level, through uncontrolled centers of power, virtual financing and organizing business, economic crises (Draskovic and Draskovic, 2009; or Strielkowski et al., 2014), and wars.

Globalization is interpreted as an ultima causa, or the general framework and context, which explains almost all developmental tendencies in the world. In this regard, V. Inozemcev (2004, p. 57) has correctly observed that globalization "has a dogmatic character of self-sustaining and natural process of the world development." However, scientists are not able to timely interpret numerous changes of the mentioned context, nor to provide their perspective. Therefore, it is very difficult to create timely and correct ways to adapt. Except for many positive achievements of globalization, perhaps its greatest achievement is that it frees the space for creativity and abolishes the limits, which have been hampering the mankind for ages in many senses: formational, ideological, political, national, organizational, management, and other. In addition, it offers the possibility of adjusting the civilized norms and achievements (particularly technological and institutional).

\section{GLOBALIZATION OF THE MEDIA}

Globalization in its most general sense is the phenomenological environment of media industry. Media globalization is a complex collection of many modern changes: cultural, economic, communication, institutional (primarily property) and other. Through the technological innovation and communication, and their application in the media, it has become "the global village" (a term by M. McLuhan - according to D. Wang, 2008, p. 203). The essence, challenges, achievements, and prospects of media globalization is vaguely interpreted. There are three theoretical approaches on the relationship between media and globalization, as well as their criticism, namely: a) developmentalism (J. Smith, 1998; Olivier de Sardan, 2005 N. Klein, 2007, Easterly, 2007), b) cultural imperialism ( Salwen, 1991; Tomlinson, 1991; Lechner, F. \& Boli, J., 2009), and c) concept of information society (Bell, 1976; Drucker, 1969; Webster, 2002; Barney, 2003; Garnham, 2004). In addition, media globalization is viewed through the prism of development (at least virtual) of collective system of different opinions, and notion of events about which interest groups, through the media imagination, try to control and discipline the citizens, and influence their opinion.

The media industry has its numerous specifics, which are determined by the changes of information exchange character, from mono-logic toward interactive, through hyper-digital dialogue at unlimited distances within the global media spectrum. The development of modern media has four parallel processes: globalization, de-mass scale, conglomeration, and convergence. Their complex and ambiguous interdependence and conditionality make those processes apparently subsumed under a common denominator, which is called globalization of media. The literature (Buburin, 2009; Bauer, 2007; Lakic, 2010) points out some rather strong negative effects of globalized media system affecting the public opinion, as well as affirmation of the specifics and differences of cultural identities (due to the strategy of unification). They are increasingly suppressed under the media pressure of uniformed patterns and the culture of globalized values (consumerism, sensationalism, and others). We believe that the complex structure of a global relation network (economic, technological, communication, organizational, geo-political, geo-economic, social, cultural, institutional, etc.) requires proper media adjustment. The negative phenomena of media globalization (Draskovic, 2011; Ederstone, 2011), through the influence of emergent signs of new concentration possibilities of the media and their power, managed to establish relationship between a hierarchy and subordination of power, restrictions and consumerism on one side, and identity crisis on the other. Viewed through the prism of traditional principles, Z. Rutovic (2015, p. 79) writes that essentially it is a crisis of meaning of the media industry. Because, media globalization leads to de-traditionalization of cultural norms and values, creating popular 
postmodern culture, commercialization of interests, paradigm of media power, mass accessibility and use of information, media convergence, discontinuity of public interes presentation, stereotypization and unification of pop-culture, identity crisis, digitalized aestheticized reality, interest projected focus of presenting the events, etc..

Apart from profitable convergence, emphasized by W. Busenberg (2015), J. Orihuela (2013) argues that new media paradigm are: new relations with audiences (interaction), new linquagves (multimedia) and a new grammar (hypertext). The profit-policy instruments of viability of new media paradigm cause new social reality, based on the growing media influence (power). This power results in (re)designing the man and the society (eg. public opinion). It is accompanied by antinomic consequence, which some authors (e.g. Esses, Medianu, and Lawson, 2013), recognize as dehumanization of the media. The favored global media power has become the supreme principle of generating media awareness.

\section{GLOBALIZATION OF THE MEDIA THROUGH THE PRISM OF RELATIONS WITH THE ECONOMY}

Explanations of the media globalization are often one-sided and deterministic. It seems that this is theoretically conditioned by the lack of a unified theory of globalization. In a practical sense it's impacted by its connection with the development imperatives and interests of big capital in specific historical circumstances. By emphasizing the motivation (interest) factors we want to point out the debatable claims of M. Castells (2000, p. 147) that the economic globalization has been predominantly politican creation. Although is true that politics dominates the economy, we believe that everything is indisputably done because of the economy. A. Cakardic (2006, p. 850) suggests that globalization indicates that society as a whole, and the system of organizing the state, are focused on the economy and reproduction of the system needs. In the same context, globalization is an understanding that the world market (or economy) dominantly suppresses political activity. These claims are also the idea of British historian G. M. Trevelyan, that politics is the consequence, not the cause of the social change.

From the aspect of media globalization and hypotheses, there are symptomatic warnings that globalization is not global because its rules do not apply equally to all aspects. In this regard, J. Stiglitz (2002, p. 248) wrote: "If globalization continues to be conducted in the way that it has been in the past, if we continue to fail to learn from our mistakes, globalization will not only succeed in promoting development, but will continue to create poverty and instability." This refers to the ambiguity in development and many other contrasts of globalization (see more in: Draskovic, 2002). Records from many publications show that a large part of humanity is far from globalization. They prove that globalization has no universality, no integrity. Therefore, many authors believe that globalization should be - globalized! The essence of economic and media globalization, understood as a qualitatively new and higher stage of mega-trendy internationalization of economic, political, cultural, organizational, and media life (Draskovic et al., 2010) indeed corresponds with the globalization of media and media markets. It is the creation of transnational media bridges in the organizational, institutional and economic terms, using global information and communication networks as a technological background. In such circumstances, external criteria (interests, power, omnipotence, and coercion) dominate over internal. This is in line with the external character and financial structures of big capital, as well as its interest-connection with political centers of power. 


\section{MEDIA AS A SATELLITE AND A ROADMAP OF GLOBAL RELATIONS BETWEEN ECONOMICS AND POLITICS}

Basic economic principles in the process of media globalization are accompanied by the omnipresent and meaningful multidimensional media reality. The media industry is actively involved in the globalization process of removing multiple borders. In addition to the creation of new borders, polarization, and problems, for our analysis are also interesting the following (reverse) economic effects. Because, modern tendencies have arisen in the context of economic homogenization of the media industry, in which the means of mass communication emerged as a powerful economic and political factor of global unification. The impact of media globalization on meaningful pluralism of the media is expressed primarily through the concentrated capital of media corporations, which produce almost unified program formats designed for the society of spectacle, as well as new media platform of convergent type.

Everyday media are filled with colorful and aggressive raports about political and economic pressures, sanctions, wars, destruction, threats, blackmail, international blockades, crises, spread of influental spheres, propaganda, corruption scandals, government and political upheavals, conditions to apply the reform programs of international institutions UN, WTO, IMF, World bank, etc. The question arises: what is their basic objective? Although it is not possible to give a one-sided answer, it seems that their background is always an interest (in political and economic terms). Because, all the previous criteria of division (political, ideological, national, class, racial, religious, etc.), in today's media are fogged, marginalized and subjugated to the basic (global) economic criteria, leading to the dominance and power of those who hold big capital. And everything else is solved through it. The dominant role of the global media helps the economic, political and other forms of competitiveness to predominantly determine the course of globalization at different levels, areas and structures.

Economic aspects of the media in global relations dominate all the others: political, informational, educational, cultural, etc.. The profitability of media subjects (giants) is increasingly becoming a priority, along with all the other side effects which it achieves, and the interests which it represents. Thereby, a little attention is paid to the relationship between profitability, social role, and responsibility of the media as a powerful tool for distortion and fixation of reality, especially where there is a perfect mental and social ground. The globalization of mass media is probably an effective way of suppressing different cultures, their transformation and modeling to the molds and requirements of the Western corporate system and consumerism. Blinded by profit, through lobbying and various narrow economic interests of its owners, the media ignore many important issues and problems, among them, for example, the impossibility of infinite economic growth based on the speculative principles of the so-called "casino economy", unequal trade, neocolonialism, technological leadership and the other.

\section{THE RATIO OF CAPITAL AND MEDIA}

In modern conditions, capital super-concentrated economic entities create the rules by which people live - dominantly, and without a transparent regulatory framework. Competition of media oligopoly companies (in global relations) through lobbying, public relations, marketing, and other modalities, disturbs the balance between profit and public good. Established "public" based on media oligopolies constitutes a new (desired, projected) critical mass, which is relatively illiterate in the media view. This is done through universalization (monopolization) of various media contents and formats. Thus are formed the "standpoints" of media audience, which lacks the sufficient knowledge and information. Hence, almost no one examines the 
motives of the capital owners, whose media are only message boards, exclusively of personal or networked business and political interests.

The media are placed in a specific socio-historical and cultural context, which is predominantly determined by capital relations, or tight interests connection between media, politics, and big capital. This is the basic characteristic of the global media market. Everything else is a matter of technical operationalization and instrumentalization. Namely, the media are managed by a strong monopoly power, whose concentration is constantly increasing and operating towards neo-imperial multi-domination. This way, influenced by money (capital), daily reality is formed and forged, established accordingly to interests - presented selectively.

The character of the social system, democratic traditions and culture could correct the mentioned views to some extent, but not to radically change the grounds of media functioning, formed under the strong pressure of concentration. The consequences of such a created reality (in value terms) are the result of concentrated capital as a media phenomenon. Similarly formatted media constitute the capital to be able to, not a word of power, information and/or the basic principles of vocational codex. From the omnipotence of capital results the inability of a man - to recognize, overcome and actively create their own opinion, and freedom of action. Changing options (imposed, proposed, suggested) in all segments offer ultramodern, wide-range and interactive technology of media mega-corporations, which limit the last remnants of human privacy and contribute to its alienation.

The structure of modern media industry essentially (elitism, domination of large capital), and on target function (supporting the interests of the powerful and expanding their power) does not differ from other economic and institutional structures. It is a neoliberal anatomy of a new power structure (money-mediatechnology), which increases through the process of media concentration (Lakic and Draskovic, 2015). The process of media concentration is just a new neo-liberal component that generates a new, additional power. As such, it perfectly fits into other components of power, and is included in the structure of the total power of media corporations.

\section{MEDIA CONCENTRATION}

Globalization is accompanied by a stormy technological development, especially information and communication innovations. It has caused an exponential development of the media industry in all of its segments: different forms of broadcasting, publishing, entertainment, and advertising. This has led to the strengthening of control over media production, employment, distribution, and audience (McQuail - by Draskovic and Grego, 2002, p. 87). Concentrated media ownership is in the possession of transnational and multinational corporations. It is the result of enormous expansion of economic and technological interests. In addition to the high share of fixed costs in total costs of the media industry (over 80\% - Mickelethcait, 1989, p. 3), the global media markets have become extremely ownership concentrated. The main objective of the medium concentrations, apart from profit, is the control of mass audience, or reality.

The logic of media concentration is clear: economy of scale reduces business risks, while increasing the high barriers of entry to a relatively defective media market (limited competition with a largely dominant oligopolistic and monopolistic market structures, numerous and powerful external effects, the effect of public goods, asymmetry of information, etc..). Many authors (Bagdikian, 2000; Picard, 1998; McChesney, 1999, 2001; Kops, 1999; Petrusko, 2003; Bibby, 2004) argue that the concentration of media has become a new form of postmodern meta-colonial force that influences individual and whole society through the reduction of freedom of expression, and restriction of democratic development. The research of concentration level in media industries is important for perceiving the control level of the media market and monopolistic price 
increases of certain media products, which increase the profits of media companies and reduce social welfare in the long run. The global media market found itself under the domination of seven multinational corporations: Disney, AOL Time Warner, Sony, News Corporation, Viacom, Vivendi, and Bertelsmann. All of them are ranked among the largest 300 non-financial companies in the world.

Recognizing and understanding the problem of media concentration, according to R. Picard (1998, p. 197), stems from the knowledge that economic and social control have a restrictive influence on the media (as substantially the state), or political control. It critically examines the connection between big media, government, financial institutions, and many other social institutions, which have always existed and directed the media behavior. The problem of media concentration has become especially apparent when changes in public policy of developed world have led to the extinction of the traditional monopoly of public services, and the creation of a parallel commercial broadcasting. However, the most "creditable"” for media concentration are large companies, having huge financial resources. The emergence and development of media conglomerates has launched significant issues related to the economic constraints of news, information, and opinions, increasing commercialization of all media through sensationalism (which serves to attract the audience), managed criticism, and censorship of political and social ideas.

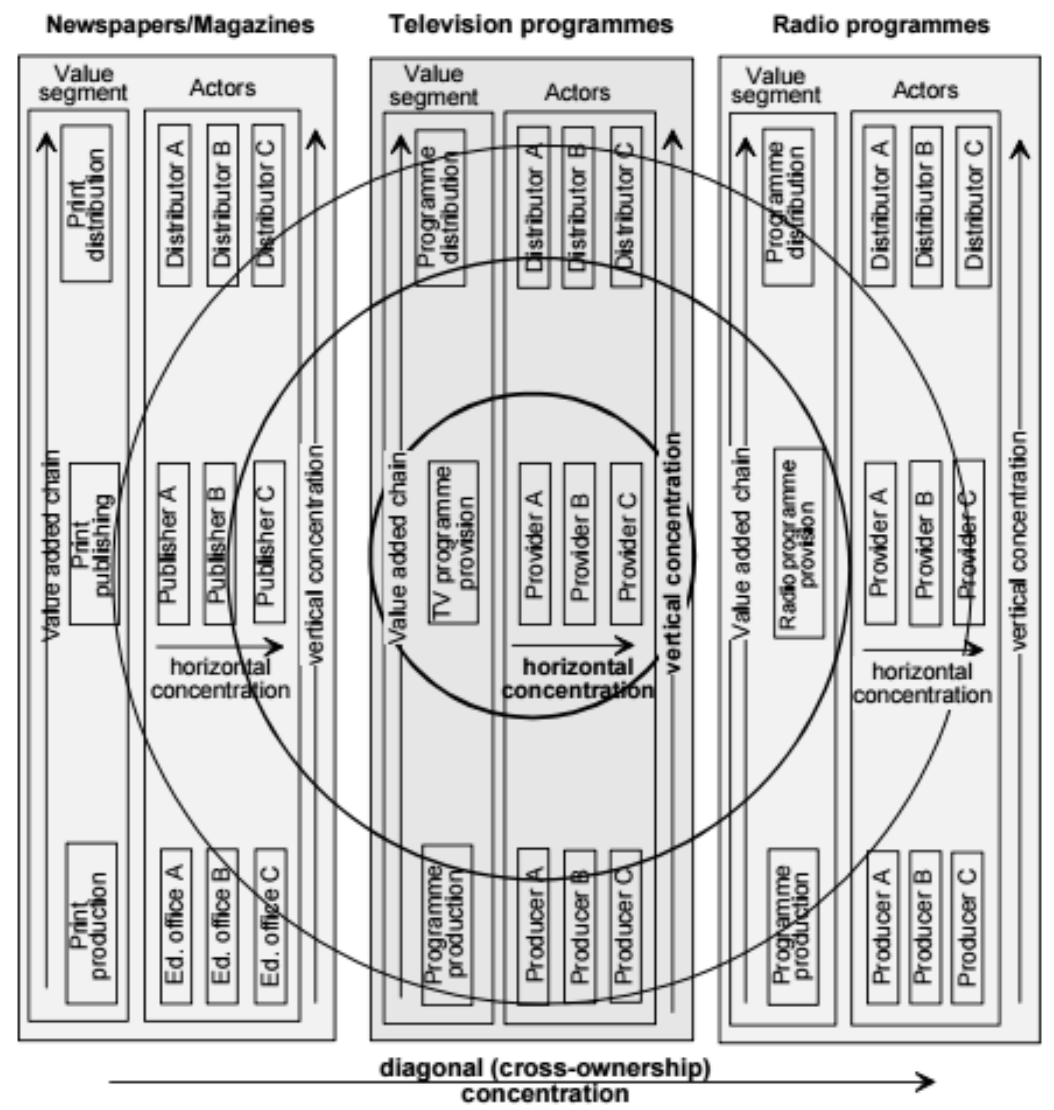

Figure 1. Forms of Concentration in the (Traditional) Media Sector

Source: Kops, 1999, p. 2. 
Horizontal and vertical concentration of ownership in the media industry is not a recent phenomenon. Yet, cross-media concetration has characterized the last two decades. Cross-ownership arises between companies operating in different but related media markets. For example, different media that are united by a common editorial guidance (press, radio, and television). Diagonal concentration first explained M. Kops (1999) - Figure 1. These phenomena are increasingly frequent, especially after the rapid infiltration of new media. However, it is not possible to research their specificity. There are several reasons for this: constant change of the rules in the concentration of media, a change in the ownership relations and their participation (Smith, 1991).

From the late 1970s and early 1980s to the present day, the mass media have been increasingly commercialized, or directed to the advertising industry and profit. This has led to changes in their functional and value components. Basic functions of the media remained informative, fun and educational, but there has been a modification in the ways of performing those functions. The established neoliberal paradigm as an ideology of big capital has gained its reflection, not only in economics and international relations, but also in the field of media policy. In every society, the mass media convey values that are incorporated into the dominant ideology. Neoliberal ideology has led to the suppression of conservative values, such as patriotism, community, morality, belief, humanity, solidarity, etc. Commercialization of the media has led to a reduction of educational and informative functions, and increasing orientation toward entertainment, virtuality, and even violence.

\section{MEDIA CONCENTRATION VS. MEDIA PLURALISM}

Media concentration strengthens with the development of new communication technologies, which encourage integration and the new types of media operators. From the perspective of media transparency it creates a double problem: 1) blurring the transparency of media ownership, and 2), complicating the activity of anti-trust authorities, which need to control media concentration. In addition, the issue of concentration and monopoly of media outlets, and the consequent creation of transnational media empires questions the independence of media, even in liberal democracies. Thus, for example, three men in Britain - Murdoch, Maxwell, and Stevens - are controlling $82 \%$ of the sales of weekly newspapers, and $73 \%$ of its daily circulation (Rutovic, 2016, p. 165). In this sense, media expert S. Basic-Hrvatin (2011, p. 7) states: "Tycoonization of the media has reached such proportions that we are approaching the former monopoly over the media, in which one or two owners controlled most of the media."

Abstracting all the negative and positive consequences of media concentration, the fact is that its existence and expansion drastically restricts the advartized competition (between different media owners, media products, and media content). It is harmful to pluralism and diversity of media (Perusko, 2003, p. 8). Furthermore, it has led to an astonishing paradox, which was noticed by Bagdikian (2000) - that privatization (deregulation) of the media has led only to a new form of regulation (private). This means that the private regulation has replaced the state, while media concentration was based on the deregulation as its own flip side! This raises the logical question: why did this happen? It seems that the best answer was given by D. Vick (2006), who believes that this is a victory of the market over social liberalism. A similar explanation was given by H. Shelanski (2002), who found that it was a victory of the model focused on the efficiency over "democratic" model of public interest.

Protection and stimulation of media pluralism and their diversity are a mandatory element of the official media policy in the European Union. It is an imperative to raise the question of stimulating media pluralism. This means regulation, restriction and prevention of monopoly, and strict control over media monopoliza- 
tion. There are two basic ways to establish and protect media pluralism: a) limiting the concentration (antitrust), and b) direct and indirect subsidizing the media within appropriate media policies. M. Drašković (2008) believes this is only way to ensure the fair and healthy competition in the media market, but also the adequate democratic development - through the possibility to approve all reasonable and advanced ideas in media as a public sphere. Unfortunately, the economic logic of profit leads to the fact that media pluralism is manifested more like rhetorics, rather then a reality. However, modern reality is a dictation of mega-media, producing meta-reality (imaginary, virtual, and spectacular reality). This has proved to be a good way of controlling not only what people do, but also what they think (Chomsky, 2006). That is a controlled or so-called "permitted opinion" by the media institutionalized structure, representing the interests of the powerful.

\section{CONCLUSION}

Media globalization in line with the contradictory context of the globalization process has led to numerous controversies and paradoxes, which clash over the eternally complex relationship between economics and politics. It is characterized by the dominance of high interest (geopolitical, geo-economic, etc.) motivation of large capital, accompanied by media concentration, propaganda and indoctrination. The broad debate on concentration in the media, strategic platforms, and the choice of value priorities in media policy is constantly up to date, as well as the evolving process. The results, in terms of limiting and controlling this concentration, are still out of reach. A key feature of concentrated and hyper-concentrated media in the last three decades has been a tendency toward neoliberal ideology. That implies the logic of large (particularly transnational) capital, corporate capitalism, ignoring local culture, replacing public education components with entertainment programs, imposing materialistic value orientation and media that promote violence, sensationalism, immorality, and social pathology. Our descriptive analysis has confirmed the proposed hypotheses regarding the existence of a reverse link between the economy and the media - economic interests of concentrated corporate media and large capital are the primary goal of media globalization. Clearly, political and media dogmatism are standards and accompanying patterns of economic thought and behavior. Profit represents both their integrator and generator.

\section{REFERENCES}

Bagdikian, B.H. (2000), The Media Monopoly, 6th edn. Boston, MA: Beacon Press.

Bandin, T. (2009), "From the Globalization Maelstrom to the Globalization Congruence as a Legal Civilization Result", Montenegrin Journal of Economics, Vol. 5, No. 9, pp. 5-13.

Barney, D. (2003), The Network Society, Cambridge: Polity.

Bauer, A. T. (2007), Mediji za otvoreno drustvo, Zagreb: ICEJ.

Bebek, S., Santini, G. (2009), „Svijet bez granica“, Ekonomija/Economics, Vol. 16, No. 2, pp. 289-310.

Bell, D. (1976), The Coming of Post-Industrial Society, New York: Basic Books.

Bibby, A. (2004), Global Concentration in the Media, Nyon (Switzerland): Union Network International.

Buzenberg, W. E. (2015), „Anatomy of a Global Investigation: Collaborative, Data-Driven, Without Borders“, Shorenstein Center on Media, Politics and Public Policy, Harvard Kennedy School, Discussion Paper Series, No. D-94 // http://journalistsresource.org/studies/society/news-media/global-investigative-journalism-collaborations-insights-new-media-paradigm\#sthash.K6AhA3jH.dpuf, (referred on 03/03/2016).

Castells, M. (2000), The Rise of the Network Society, Oxford: Blackwells.

Chomsky, N. (2006), Mediji, propaganda, sistem, Zagreb: Što čitaš. 
Č́belková, I., Strielkowski, W., Mirvald, M. (2015), „Business influence on the mass media: a case study of 21 countries", Transformation in Business \& Economics, Vol. 14, Issue 1, pp. 65-75

Čakardić, A. (2006), Globalna neoliberalna demokracija u 'minimalnoj' državi, Filozofska istraživanja, Vol. 26, No. 104, pp. 849-860.

Drašković, M. (2008), Menadžment u kulturi medija, Podgorica: ELIT.

Draskovic, M. (2011), “Concentration of Media Ownership as a Global Phenomenon”, Montenegrin Journal of Economics, Vol. 7, No. 2, pp. 145-152.

Draskovic, V. (2010), "The Real Institutionalization as a Condition of the Efficient Economic Politics and Economic Development", Montenegrin Journal of Economics, Vol. 7, No. 1, pp. 5-20.

Draskovic, V. (2010a), "Neoliberal Myths of Globalisation and Pseudo-Market Transition Economies", Montenegrin Journal of Economics, Vol. 6, No. 11, pp. 9-16.

Draskovic, V., Grego, Z. (2002), "Media Concentration, Neoliberal Paradoxes and Increase in Virtuality", Montenegrin Journal of Economics, Vol. 7, No. 2, pp. 85-98.

Draskovic, V., Jovovic, R. (2006), "Globalization in Economics Contects", Montenegrin Journal of Economics, Vol. 2, No. 1, pp. 75-88.

Draskovic, V., Draskovic, M. (2009), "Priority of the Anti-Crisis Economic Policy Based on Innovative-Institutional Changes", Montenegrin Journal of Economics, Vol. 5, No. 10, pp. 47-52.

Draskovic, V., Delibasic, M. (2014), "Neoliberal Rhetoric as a Metaphor for Quasi-Institutional Monism”, Montenegrin Journal of Economics, Vol. 10, No. 2, pp. 33-47.

Drucker, P. (1969) The Age of Discontinuity, London: Heinemann.

Easterly, W. (2007), The Ideology of Development, Foreign Policy, July/August, pp. 30-35.

Ederstone M.T. (2011), "Media Concentration in Australia", Montenegrin Journal of Economics, Vol. 7, No. 2, pp. 139-144.

Esses, V. M., Medianu, S., Lawson, A. S. (2013), „Uncertainty, Threat, and the Role of the Media in Promoting the Dehumanization of Immigrants and Refugees", Journal of Social Issues, Vol. 69, No. 3, pp. 518-536.

Garnham, N. (2004), "Information Society Theory as Ideology", In F. Webster Ed. (2004), The Information Society Reader, London: Routledge.

Inozemcev, V. (2004), „Vesternizatsiya kak globalizatsiya i globalizatsiya kak amerikanizatsiya”, Voprosy filosofii, No. 4, pp. 57-69.

Klein, N. (2007), The Shock Doctrine: The Rise of Disaster Capitalism, New York: Metropolitan Books.

Kops, M. (1999), „Combating Media Concentration in a Globalising World Economy“, Working Paper, No. 118, Germany: Institute for Broadcasting Economics University of Cologne, pp.1-41 // http://www.rundfunk-institut. uni-koeln.de/sites/rundfunk/Arbeitspapiere/118_99.pdf (referred on 21/02/2016).

Lakić, S., (2010), "Medijski propagandizam novog svjetskog poretka”, Medijski dijalozi, Vol. 3, No. 6, pp. 99-114.

Lakic, S., Draskovic, M. (2015), „Implications of Institutional Dispositions of Neoliberalism“, Montenegrin Journal of Economics, Vol. 11, No. 2, pp. 113-124.

Lechner, F., Boli, J. (2009), The Globalization Reader, New York: Wiley-Blackwell.

McChesney, R. W. (1999), “The New Global Media, It's a Small World of Big Conglomerates”, The Nation Magazine, 29 November.

McChesney, R. W. (2001), “Global Media, Neoliberalism, and Imperialism”, Montly Review, Vol. 52, no. 10, pp. 1-19.

Mickelethcait, J. (1989), "The Entertainment Industry”, The Economist, 23 December.

Olivier de Sardan, J-P. (2005), Anthropology and Development: Understanding Contemporary Social Change, New York: Zed Books Ltd.

Orihuela, J. L. (2013), eCommunication: The 10 Paradigms of Media in tge Digital Age, II A20 COST Conference Towards New Media Paradigms // http://www.slideshare.net/jlori/orihuela-cost-paper (referred on 06/03/2016) 
Peruško, Z. (2003), “Medijska koncentracija: izazov pluralizmu medija u Srednjoj i Istočnoj Europi”, Medijska istraživanja, Vol. 9, No. 1, pp. 39-58.

Picard, R. G., (1998), "Media Concentration, Economics, and Regulation", in Graber, D., McQuail, and Norrsi, P., ed., Title Politics of News, The News of Politics, Wasgington D.C.: Congressional Quarterly Press, pp. 193-217.

Rutović, Ž. (2016), Sociološki aspekti posljedica globalizacije medija, doctoral thesis, Podgorica: Univerzitet Crne Gore.

Salwen, M. B. (1991), „Critical Studies in Mass Communication“, Cultural Imperialism: A Media Effects Approach, Vol. 8, No. 1, pp. 29-38.

Shelanski, H. A. (2002), „From sector-specific regulation to antitrust law for US telecommunications: the prospects for transition", Telecommunications Policy, No. 26, pp. 335-355.

Smith, A. (1991), The Age of Bahemots: The Globalization of Mass Media Firms, New York: Priority Press.

Stiglitz, J. (2002), Globalization and its Discontents, New York: W.W. Norton\&Company.

Strielkowski, W., Hejlová, D., \& Kisileva, L. (2014), „Economic factors influencing wellbeing and the quality of life". Journal of Applied Economic Sciences, Vol. 9, Issue 3, pp. 488-494

Tomlinson, J (1991), Cultural imperialism: a critical introduction, New York: Continuum International Publishing Group.

Vick, D. W. (2006), „Regulatory convergence?“, Legal Studies, Vol. 26, No. 1, pp. 26-64.

Wang, D. (2008), „Globalization of the Media: Does It Undermine National Cultures?“, Intercultural Communication Studies, Vol. 17, No. 2, pp. 203-211.

Webster, F. (2002), Theories of the Information Society, Cambridge: Routledge. 